\title{
VIABILITY AND COLONY MORPHOLOGY VARIATION OF RHODOCOCCUS RHODOCHROUS CNMN-AC-05 IN THE PRESENCE OF MAGNETITE NANOPARTICLES
}

\author{
O. Postolachi ${ }^{1}$, I. Rastimesina ${ }^{1}$, V. Josan ${ }^{1}$, T. Gutul ${ }^{2}$ \\ ${ }^{1}$ Institute of Microbiology and Biotechnology, \\ 1 Academiei Str., Chişinău, MD-2028, Republic of Moldova \\ ${ }^{2}$ Institute of Electronic Engineering and Nanotechnologies 'D. Ghitu', \\ 3/3 Academiei Str., Chişinău, MD-2028, Republic of Moldova \\ e-mail:oleseap@yahoo.com
}

In recent decades the use of nanotechnologies in the remediation of xenobiotic substances has proven its effectiveness, but not its safety. Nanoparticles often accumulate in the remedied environment, having, over time, toxic effects on living organisms. In this context, research on the vital activity of microorganisms and their interaction with nanoparticles is of major importance. Aim of the research was to determine the influence of $\mathrm{Fe}_{3} \mathrm{O}_{4}$ nanoparticles, obtained by different ways (laboratory method and synthesis in the reactor) on the viability and colony morphology of Rhodococcus rhodochrous CNMN-Ac-05 strain. Methods. Encapsulated magnetite $\left(\mathrm{Fe}_{3} \mathrm{O}_{4}\right)$ nanoparticles were synthesized by chemical co-precipitation method, using iron(II) sulfate and iron(III) chloride in the presence of poly-N-vinylpyrrolidone, used as a stabilizer. $\mathrm{Fe}_{3} \mathrm{O}_{4} \mathrm{SR}$ (Synthesis in the Reactor) was produced in the multifunctional reactor VGR-50, at the same conditions. Cell biomass was determined on the spectrophotometer by the optical density at $540 \mathrm{~nm}$, with subsequent recalculation to cell dry weight according to the calibration curve. The cell dry weight was determined by gravimetric method. The morphological features of the rhodococci colonies were described according to the standard microbiological method. Results. It was established that magnetite nanoparticles in concentrations of $1-100 \mathrm{mg} / \mathrm{L}$ were not toxic to the $R$. rhodochrous strain, had a positive effect on the viability of rhodococci by stimulating the growth of biomass, regardless of their concentration and the method of their synthesis. In the presence of $\mathrm{Fe}_{3} \mathrm{O}_{4}$ nanoparticles the population dissociated to $S 1, S 2, R 1, R 2$ forms, and $S$-R type of colonies, while the basic morphological features of $R$. rhodochrous colonies corresponded to type S1. Conclusions. The optimal concentration of magnetite nanoparticles, which stimulated the growth and development of $R$. rhodochrous was $25 \mathrm{mg} / \mathrm{L} \mathrm{for} \mathrm{Fe}_{3} \mathrm{O}_{4}$ and $50 \mathrm{mg} / \mathrm{L}$ $\mathrm{Fe}_{3} \mathrm{O}_{4} \mathrm{SR}$. At all concentration of $\mathrm{Fe}_{3} \mathrm{O}_{4}$ nanoparticles the main colony morphotype of the rhodococci was smooth S1-type; the new types of colonies represented only 0.1-0.6\% of the population, and the lowest degree of variability corresponded with the highest colony-forming units index.

Keywords: rhodococci, magnetite NPs, colony morphology.

Actinobacteria of the genus Rhodococcus are widespread in the natural environment, including soils, rocks, boreholes, groundwater, marine sediments, animal dung, insect guts, even in healthy and diseased animals and plants [1]. Rhodococcus spp. is able to survive in the presence of high doses of toxic compounds, as well as under desiccation conditions, carbon starvation, a wide range of temperatures (from 4 to $45^{\circ} \mathrm{C}$ ), UV irradiation and osmotic stress [2-5]. Rhodococcus strains are often isolated from environments where hydrocarbons are present [6].

The ability of these non-sporulating bacteria to survive in hostile environmental conditions is due to their impressive biosynthetic capabilities. Beside the large set of enzymes (dehydrogenases, peroxidases, oxygenases, alkylsulphatases, nitrilhydratases, and phenolhydrolases) the Rhodococcus spp. produce glycolipid biosurfactants and bio-flocculation agents, especially acrylamide, triacylglycerols, carotenoids, and polyhydroxyalkanoates (PHAs) $[3,7,8]$. The metabolic versatility of rhodococci makes them well-equipped for industrial uses, such as biotransformation and the biodegradation of xenobiotic compounds [8,9].

More recently, nanoparticles (NPs) of different nature are used to enhance the biodestructive capabilities of the rhodococci [10-14]. Particular 
attention is paid to the iron oxide NPs (IONs), which, besides having a large surface area to volume ratio, possess such unique properties as superparamagnetism and biocompatibility. Most commonly, magnetite NPs are used to immobilize cells of microorganisms. This method has two main advantages: it enhances the biodegradation activity of immobilized Rhodococcus spp. and facilitates the recovery and reuse of cells decorated with magnetic NPs [10-13].

Iron NPs have no inhibitory and adverse effect on Rhodococcus spp. cells growth and survival, however bacteria exhibit various metabolic responses upon interaction with iron NPs, and the potential applications of IONs depends on their physicochemical characteristics and surface properties of bacterial cells as well as environmental/culture conditions $[11,13]$. It is well known that in biological media iron NPs are oxidized, generating reactive oxygen species (ROS), which are responsible for inducing oxidative stress in living organisms $[15,16]$. Whatever the conditions of stress, microorganisms respond by starting the mechanisms of the phenomenon of cellular heterogeneity, meant to ensure the survival of the population $[5,17,18]$. Bacteria of the genus Rhodococcus are not an exception $[19,20]$.

Our laboratory holds the Rhodococcus rhodochrous CNMN-Ac-05 strain, which is a destructor of benzothiazole and its metabolites [21]. Combination of $R$. rhodochrous CNMNAc-05 with magnetite NPs would allow recovering and reusing of the strain in several cycles of degradation. For this reason, the purpose of our research was to determine the influence of magnetite NPs on the viability and colony morphology of $R$. rhodochrous CNMN-Ac-05 strain.

\section{Materials and methods}

Chemicals. Iron(II) sulfate $(\geq 99.7 \%$ ), a saturated iron(III) chloride solution ( $\geq 99.0 \%$ ), poly- $N$-vinylpyrrolidone (PVP, MW: 8000), and ammonium hydroxide $(\geq 99.9 \%$ ) were purchased from Sigma-Aldrich. All chemicals used in this study were of analytical grade and commercially available.

Nanomaterials. Encapsulated magnetite $\left(\mathrm{Fe}_{3} \mathrm{O}_{4}\right)$ NPs were synthesized by chemical coprecipitation method, using iron(II) sulfate and iron(III) chloride in the presence of poly- $\mathrm{N}$ vinylpyrrolidone (PVP) used as a stabilizer [22]. $\mathrm{Fe}_{3} \mathrm{O}_{4} \mathrm{SR}$ (Synthesis in the Reactor) was produced in the multifunctional reactor VGR-50, at the same conditions.

Bacterial strain and culture conditions. R. rhodochrous CNMN-Ac-05 was deposited in the National Collection of Non-Pathogenic Microorganisms of the Republic of Moldova, and was able to degrade benzothiazoles, persistent organic pollutants [21]. R. rhodochrous CNMNAc-05 was grown in $100 \mathrm{~mL}$ portions of Tryptic soy (TS) broth (Sigma-Aldrich) in $300 \mathrm{~mL}$ Erlenmeyer flasks incubated at $28{ }^{\circ} \mathrm{C}$ and $200 \mathrm{rpm}$. The cells were harvested after $36 \mathrm{~h}$ of culture and centrifuged at $6.000 \mathrm{rpm}$ for $20 \mathrm{~min}$. The bacterial pellet was washed first with a $\mathrm{NaCl}$ solution $(0.8 \%)$ and then with distillated water.

Determination the effects of magnetite. Bacterial biomass was resuspended in distillated water ( $\mathrm{pH}$ 7.2) to prepare cell suspension $6 \mathrm{mg} / \mathrm{mL}$ (1.4 mg of cell dry weight $/ \mathrm{mL}$ ). Colloidal aqueous solutions of magnetite, $2 \mathrm{mg} / \mathrm{mL}$, were prepared on ultrasonic cleaner at $50 \mathrm{kHz}$ for $5 \mathrm{~min}$. For experiments, $5 \mathrm{~mL}$ of bacterial cells suspension was added in $250 \mathrm{~mL}$ Erlenmeyer flasks containing $95 \mathrm{~mL}$ of PAS medium and $\mathrm{Fe}_{3} \mathrm{O}_{4}$ or $\mathrm{Fe}_{3} \mathrm{O}_{4}$ SR in the following concentrations $(\mathrm{mg} / \mathrm{L}): 1,10$, 25,50 , and 100 . The PAS medium contained $(\mathrm{g} / \mathrm{L}): \mathrm{K}_{2} \mathrm{HPO}_{4}-4.35, \mathrm{KH}_{2} \mathrm{PO}_{4}-1.7, \mathrm{NH}_{4} \mathrm{Cl}-2.1$, $\mathrm{MgSO}_{4}-0.2, \mathrm{MnSO}_{4}-0.05, \mathrm{FeSO}_{4} \cdot 7 \mathrm{H}_{2} \mathrm{O}-0.01$, $\mathrm{CaCl}_{2} \cdot 2 \mathrm{H}_{2} \mathrm{O}-0.03$ [23]. $\mathrm{pH}$ adjusted at 7.2. Inoculated flasks were incubated in a rotary shaker $(180 \mathrm{rpm})$ at $28^{\circ} \mathrm{C}$ for $24 \mathrm{~h}$. After the serial dilution the $50 \mu \mathrm{L}$ of suspension was spread on agar plates with TS medium, the plates were incubated at $28^{\circ} \mathrm{C}$ for $96 \mathrm{~h}$, for the appearance of bacterial colonies. The number of viable bacterial cells was estimated by colony-forming units (CFU) inoculated on agar plates.

Cell biomass was determined on the spectrophotometer by the optical density at $540 \mathrm{~nm}$, with subsequent recalculation to cell dry weight according to the calibration curve. The cell dry weight was determined by gravimetric method, drying biomass at $105^{\circ} \mathrm{C}$.

The morphological features of the rhodococci colonies were described according to method [24] using a magnifying glass (8-fold magnification).

Statistical analysis was performed using MS Excel. All results were expressed as mean of three individual replicates $\pm \mathrm{CI}$ (confidence intervals). All differences were considered significant at $\mathrm{P}<0.05$.

Results. Testing of the action of nanomagnetite, obtained by different ways (laboratory method 
and in the reactor), on the viability of the $R$. rhodochrous CNMN-Ac-05 strain showed that regardless of the method used, magnetite NPs stimulates the growth of rhodococci cells. However, there was a difference in the response of rhodococci to the presence of magnetite NPs.

Thus, the optimal concentration of $\mathrm{Fe}_{3} \mathrm{O}_{4} \mathrm{NPs}$, which stimulated the growth and development of the $R$. rhodochrous strain with $147.8 \%$ compared to the control, was $25 \mathrm{mg} / \mathrm{L}$ (Fig. 1). At higher concentrations of $\mathrm{Fe}_{3} \mathrm{O}_{4}$ NPs the viability of bacterial cells decreased considerably by 1.7 times
$(50 \mathrm{mg} / \mathrm{L})$ and 2.2 times $(100 \mathrm{mg} / \mathrm{L})$, but exceeded the control by $50 \%$ and $13 \%$ respectively.

At concentrations of $1-25 \mathrm{mg} / \mathrm{L}$ the $\mathrm{Fe}_{3} \mathrm{O}_{4} \mathrm{SR}$ NPs also stimulated the growth of Rhodococcus cells, but CFU values were on 11-32\% lower, compared with $\mathrm{Fe}_{3} \mathrm{O}_{4}$ NPs. The most favorable concentration of $\mathrm{Fe}_{3} \mathrm{O}_{4}$ SR NPs for the growth and multiplication of rhodococci was $50 \mathrm{mg} / \mathrm{L}$, the cell biomass exceeded the control by $176.1 \%$. But doubling this concentration led to a significant decrease in the number of bacterial cells, however the CFU values exceeded the control by $63 \%$ (Fig. 1)

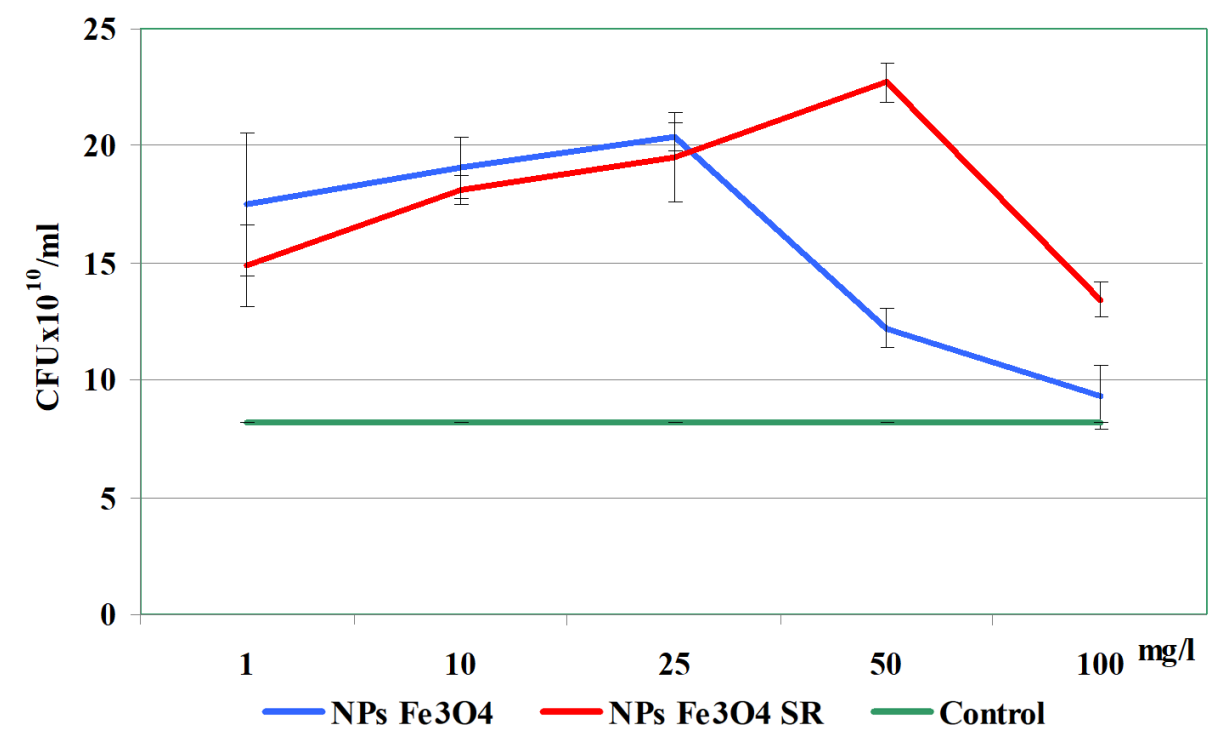

F i g. 1. Influence of magnetite NPs on the viability of $R$. rhodochrous CNMN-Ac-05 strain

In addition to cells multiplication, the morphological modification of $R$. rhodochrous CNMNAc-05 colonies under magnetite NPs was established. Macroscopically observable features and colony types of Rhodococcus are presented in Table 1 and Fig. 2.

Basic morphological features of $R$. rhodochrous CNMN-Ac-05 colonies corresponded to type S1 and this type was predominant in all experimental variants. Regardless of the nanomaterial used, the share of S1 type colonies varies in the range of $99.1-100 \%$. On TS medium without NPs (control variant) type S1 made up $100 \%$.

In the presence of $\mathrm{Fe}_{3} \mathrm{O}_{4} \mathrm{NPs}$, in all experimental variants appeared colonies of morphotype R1, which made up $0.3-0.5 \%$ of the population (Table 2). The addition of $\mathrm{Fe}_{3} \mathrm{O}_{4}$ NPs in concentration of $100 \mathrm{mg} / \mathrm{L}$ led not only to the decrease in the number of CFU, but also to the dissociation of the strain in 4 types of colonies S1, S2, R1 and S-R, however, the basic type S1, remained predominantly $-99.5 \%$.
Rhodococci growth in the presence of $\mathrm{Fe}_{3} \mathrm{O}_{4}$ SR NPs also led to the appearance of new types of colonies, but not in all experimental variants (Table 2). At concentrations of 25 and $50 \mathrm{mg} / \mathrm{L}$ the bacterial population remained homogeneous, being composed of $100 \% \mathrm{~S} 1$ type colonies. At the concentration of $10 \mathrm{mg} / \mathrm{mL}$, the appearance of $\mathrm{R} 1$ and S-R types was registered; and increase in concentration to $100 \mathrm{mg} / \mathrm{L}$ of $\mathrm{Fe}_{3} \mathrm{O}_{4}$ SR NPs led not only to the sudden decrease in the number of CFU, but also to the dissociation of the Rhodococcus population in 4 types of colonies - S1, R1, R2 and S-R.

Discussion. Traditionally, ecosystems and microbial communities have been studied as an ensemble of different monoclonal populations. It is considered that each population is composed of genetically identical cells that perform the same metabolic function. The development of single-cell resolution techniques has made it possible to highlight cell fractions in an isogenic 
Table 1

Colony morphotypes formed by $R$. rhodochrous CNMN-Ac-05 strain

\begin{tabular}{|l|c|c|c|c|c|c|c|}
\hline $\begin{array}{l}\text { Colony } \\
\text { morpho } \\
\text { type }\end{array}$ & Form & Size, $\mathbf{m m}$ & Margin & Elevation & Surface & Color & Opacity \\
\hline S1 & Round & $1.0-4.0$ & Entire & Convex & Smooth and glistening & Pink & Opaque \\
\hline S2 & Round & $3.0-3.5$ & Entire & Umbonate & Smooth and glistening & $\begin{array}{c}\text { The center light } \\
\text { pink, } \\
\text { the edges dark } \\
\text { pink }\end{array}$ & Opaque \\
\hline R1 & Irregular & $1.0-4.0$ & Undulate & Convex & Rough and dull & Pink & Opaque \\
\hline R 2 & Round & 2.0 & Entire & Umbonate & Wrinkled and dull & Pink & Opaque \\
\hline S-R & $\begin{array}{c}\text { Round / } \\
\text { Irregular }\end{array}$ & $2.5-3.0$ & $\begin{array}{c}\text { Entire/ } \\
\text { Undulate }\end{array}$ & Convex & $\begin{array}{c}\text { Smooth /Rough and } \\
\text { Glistenin / Dull }\end{array}$ & Pink & Opaque \\
\hline
\end{tabular}

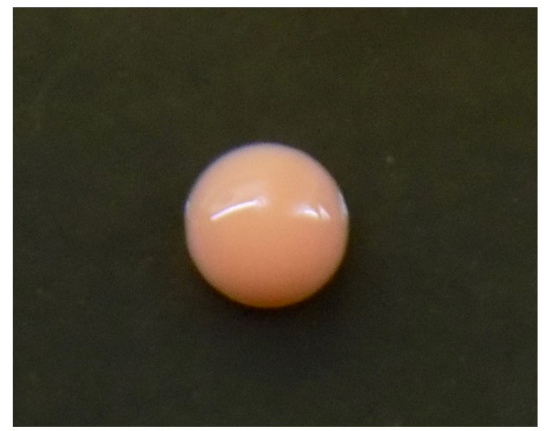

Type S1

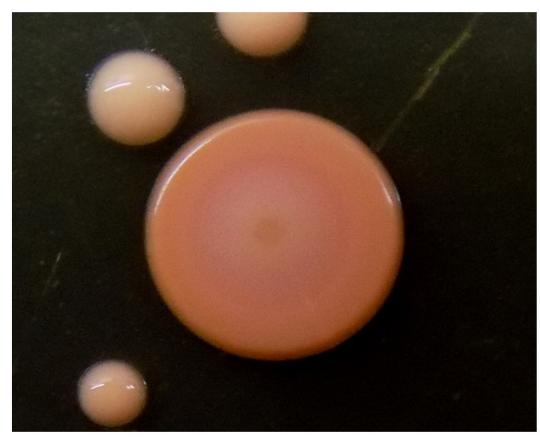

Type S2

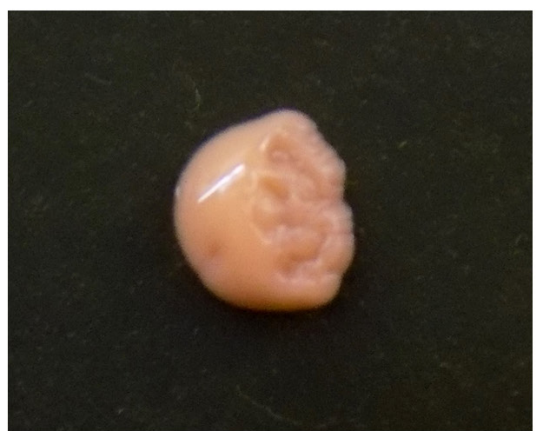

Type S-R

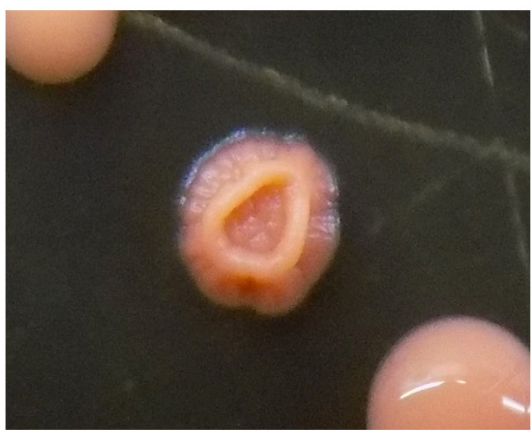

Type R1

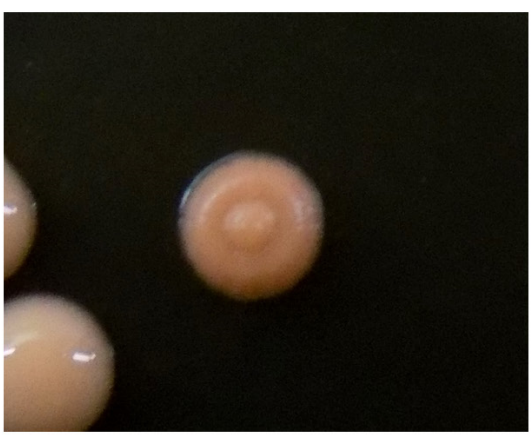

Type R2

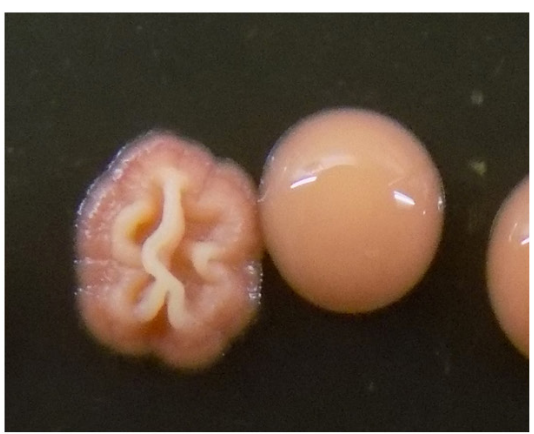

Types R1 and S1

F i g. 2. Morphological modification of colonies formed by strain $R$. rhodochrous CNMN-Ac-05 cultivated in the presence of magnetite NPs 
Table 2

The variation in colony morphology of $R$. rhodochrous CNMN-Ac-05 strain grown in the presence of $\mathrm{Fe}_{3} \mathrm{O}_{4} \mathrm{NPs}$

\begin{tabular}{|c|c|c|c|}
\hline \multirow{2}{*}{ Concentration of magnetite NPs, mg/L } & \multirow{2}{*}{ Types of colonies } & \multicolumn{2}{|c|}{ Share, $\%$} \\
\hline & & $\mathrm{Fe}_{3} \mathrm{O}_{4} \mathrm{NPs}$ & $\mathrm{Fe}_{3} \mathrm{O}_{4}$ SR NPs \\
\hline Control & S1 & 100 & 100 \\
\hline \multirow{2}{*}{1.0} & S1 & 99.6 & 99.5 \\
\hline & $\mathrm{R} 1$ & 0.4 & 0.5 \\
\hline \multirow{3}{*}{10.0} & $\mathrm{~S} 1$ & 99.5 & 99.1 \\
\hline & R1 & 0.5 & 0.6 \\
\hline & S-R & - & 0.3 \\
\hline \multirow{2}{*}{25.0} & $\mathrm{~S} 1$ & 99.7 & 100 \\
\hline & R1 & 0.3 & - \\
\hline \multirow{2}{*}{50.0} & $\mathrm{~S} 1$ & 99.6 & 100 \\
\hline & R1 & 0.4 & - \\
\hline \multirow{5}{*}{100.0} & S1 & 99.5 & 99.6 \\
\hline & S2 & 0.13 & - \\
\hline & R1 & 0.24 & 0.2 \\
\hline & $\mathrm{R} 2$ & - & 0.1 \\
\hline & S-R & 0.13 & 0.1 \\
\hline
\end{tabular}

Legend: Meaning of abbreviations see in Table 1.

population that behaves differently from others, even if environmental conditions have not changed significantly. The phenomenon, when genetically identical cells manifest cell-to-cell variability, even when sharing the same environmental and nutritional conditions, is known as phenotypic heterogeneity $[25,26]$.

Phenotypic heterogeneity is a very important means by which many bacterial populations adapt to changing environments $[17,26]$. During its evolution, bacteria have developed multiple strategies to cope with rapid and frequent changes in their environment: spore formation, changes in polysaccharide production, motility or in metabolic capacity, antibiotic response and many more [26].

The phenomenon of phenotypic heterogeneity is quite common in coryneform and nocardioform bacteria. The splitting of a homogeneous rhodococci population into variants with different morphological, physiological, biochemical, and genotypic properties have been observed by many researchers. For example $R$. opacus $1 \mathrm{CP}$ strain grown on chlorophenols has dissociated on two morphologically and physiologically distinct variants and a labile transitional variant, which was an intermediate case [19,27]. Studying of the ability of actinobacteria $R$. opacus $1 \mathrm{CP}$ to survive under unfavorable conditions (starvation, oxidative stress, low temperature $\left(4^{\circ} \mathrm{C}\right)$, and dehydration) has revealed that general strategy for survival was decreased cell size/volume and formation of densely-packed cell conglomerates [20]. Modifications in cell viability, cell morphology, membrane permeability, lipid profile, carotenoid pigments profile and 16S rRNA gene were revealed for $R$. erythropolis cells grown in the presence of $1 \%$ alkanes (cyclohexane, $n$-hexane, $n$-decane) and aromatics (toluene, styrene, ethylbenzene) [28]. In our studies, the appearance of colonies of type $\mathrm{R}$ and altercolor occurred after the contact of $R$. rhodochrous with various solid matrices, which were used for microorganism's immobilization. Moreover, the frequency of dissociation and the degree of variability of bacteria depended on the nature of the substrate [29].

A relationship between colony morphotypes formed by $R$. rhodochrous and its tolerance to aromatic substances was demonstrated [30]. Since the ability to exhibit a high level of metabolic activity is linked with the nature of bacterial growth and belonging to a certain morphological type, it is important to determine the nature of the effect of NPs on the growth and heterogeneity of the studied bacterial culture.

In our research, magnetite NPs had a positive effect on the viability of $R$. rhodochrous CNMNAc-05 cells. In all experimental variants, regardless of the NPs used and their concentration, growth stimulation was established, and the amount of biomass exceeded the control values. However, the 
maximum peak of biomass accumulation differs depending on the concentration and the method of preparing of magnetite NPs, in the case of NPs $\mathrm{Fe}_{3} \mathrm{O}_{4}$ the optimal concentration was $25 \mathrm{mg} / \mathrm{L}$, and in the case of $\mathrm{NPs} \mathrm{Fe}_{3} \mathrm{O}_{4} \mathrm{SR}-50 \mathrm{mg} / \mathrm{L}$.

There are also differences in colony dissociation of the Rhodococcus population. In the presence of $\mathrm{Fe}_{3} \mathrm{O}_{4}$ NPs in all experimental variants, along with the basic type S1, colonies of the R1 type appeared. At the concentration of $100 \mathrm{mg} / \mathrm{L}$, together with a considerable biomass reduction, the strain dissociated in 4 types of colonies - S1, S2, R1, and S-R.

The effect of $\mathrm{Fe}_{3} \mathrm{O}_{4}$ SR NPs on natural variability of rhodococci colony morphotypes did not correlate with the concentration. As in the previous case, the increase in concentration to $100 \mathrm{mg} / \mathrm{L}$ coincided with the significant decrease in biomass and the highest degree of dissociation of the

\section{ЖИТТЕЗДАТНІСТЬ І МОРФОЛО- ГІЧНА ВАРІАБЕЛЬНІСТЬ КОЛОНІЙ RHODOCOCCUS RHODOCHROUS CNMN-AC-05 У ПРИСУТНОСТI НАНОЧАСТИНОК МАГНЕТИТУ}

\section{О. Постолакі ${ }^{1}$, I. Растімешіна ${ }^{1}$, В. Жосан ${ }^{1}$ Т. Гуцул ${ }^{2}$}

\section{Iнститут мікробіології та біотехнологї, Вул. Академічна, 1, Кишинів, MD-2028, Республіка Молдова \\ ${ }_{2}^{2}$ Iнститут електронної інженерії та нанотехнологій ім. Д. Гіиу, \\ Вул. Академічна, 3/3, Кишинів, MD-2028, Республіка Молдова}

\section{Резюме}

За останні десятиліття використання нанотехнологій для детоксикації ксенобіотиків довело свою ефективність, але не безпеку. Наночастинки часто накопичуються у середовищі та 3 часом починають токсично впливати на живі організми. У цьому контексті дослідження життєздатності мікроорганізмів за умов їх взаємодії 3 наночастинками має важливе значення. Метою досліджень було визначити вплив наночастинок $\mathrm{Fe}_{3} \mathrm{O}_{4}$, отриманих різними способами (лабораторним методом та шляхом синтезу у реакторі), на життєздатність та морфологію колоній штаму R. rhodochrous CNMN-Ac-05. Методи. Наночастинки інкапсульованого магнетиту $\left(\mathrm{Fe}_{3} \mathrm{O}_{4}\right)$ синтезували хімічним методом спільного осадження з використанням сульфату заліза (II) та хлориду bacterial population (4 types of colonies - S1, R1, $\mathrm{R} 2$ and S-R).

Conclusions. In conclusion the optimal concentration of magnetite NPs, which stimulated the growth and development of the $R$. rhodochrous was $25 \mathrm{mg} / \mathrm{L}$ for $\mathrm{Fe}_{3} \mathrm{O}_{4}$ and $50 \mathrm{mg} / \mathrm{L}$ for $\mathrm{Fe}_{3} \mathrm{O}_{4} \mathrm{SR}$. However, it should be noted that in the presence of magnetite NPs the variation in colony morphology of the rhodococci was quite low; the new types of colonies represented only $0.1-0.6 \%$ of the population, and the lowest degree of variability corresponded with the highest CFU index. This allows us to conclude that the studied magnetite $\mathrm{NPs}$, in concentrations of $1-100 \mathrm{mg} / \mathrm{L}$, were not toxic to $R$. rhodochrous CNMN-Ac-05 strain, and can be used to obtain bio-nano-systems.

Funding. The study was performed within the Moldova-Belarus Bilateral Project 19.80013.51.07.09A/BL.

заліза (III) у присутності полі-N-вінілпіролідону, який використовували в якості стабілізатору. $\mathrm{Fe}_{3} \mathrm{O}_{4} \mathrm{SR}$ (синтезовані в реакторі) отримували в багатофункціональному реакторі VGR-50 за тих самих умов. Біомасу клітин визначали на спектрофотометрі за оптичною щільністю при 540 нм 3 подальшим перерахунком на суху масу клітин згідно калібрувальної кривої. Суху масу клітин визначали гравіметричним методом. Морфологічні особливості колоній Rhodococcus описували за звичайним мікробіологічним методом. Результати. Встановлено, що наночастинки магнетиту в концентраціях 1-100 мг/л не токсичні для штаму $R$. rhodochrous, позитивно впливали на життєздатність родококів, стимулюючи накопичення біомаси незалежно від їх концентрації та способу синтезу. За наявності наночастинок $\mathrm{Fe}_{3} \mathrm{O}_{4}$ популяція дисоціювала, утворюючи колонії типу S1, S2, R1, $\mathrm{R} 2$ та S-R, тоді як основні морфологічні ознаки колоній $R$. rhodochrous у контролі відповідали типу $\mathrm{S} 1$. Висновки. Оптимальна концентрація наночастинок магнетиту, яка стимулювала ріст і розвиток R. Rhodochrous, становила 25 мг/л для $\mathrm{Fe}_{3} \mathrm{O}_{4}$ та 50 мг/л для $\mathrm{Fe}_{3} \mathrm{O}_{4} \mathrm{SR}$. При всіх концентраціях наночастинок $\mathrm{Fe}_{3} \mathrm{O}_{4}$ основним морфотипом колоній родококів був гладкий тип $\mathrm{S} 1$; нові типи колоній представляли лише $0,1-0,6 \%$ популяції, а найнижчий ступінь мінливості відповідав найвищому індексу колонієутворюючих одиниць.

Ключові слова: родококи, наночастинки магнетиту, морфологія колоній. 
1. Jones AL, Goodfellow M, Genus IV. Rhodococcus. In: Whitman WB, Goodfellow M, Kämpfer P, Busse H-J, Trujillo ME, Ludwig W, editors. Bergey's Manual of Systematic Bacteriology, Second edition, Volume 5: The Actinobacteria. Springer Science \& Business Media; 2012. p. 437-448.

2. Alvarez HM, Silva RA, Cesari AC, Zamit AL, Peressutti SR, Reichelt R, et al. Physiological and morphological responses of the soil bacterium Rhodococcus opacus strain PD630 to water stress. FEMS Microbiol Ecol. 2004; 50:75-86.

3. Belfiore C, Curia MV, Farias ME. Characterization of Rhodococcus sp. A5 $5_{\text {wh }}$ isolated from a high altitude Andean lake to unravel the survival strategy under lithium stress. Rev Argent Microbiol. 2018; 50(3):311-322.

4. LeBlanc JC, Gonçalves ER, Mohn WW. Global response to desiccation stress in the soil actinomycete Rhodococcus jostii RHA1. Appl Environ Microbiol. 2008; 74:2627-2636.

5. Magdanova LA, Golyasnaya NV. Heterogeneity as an adaptive trait of microbial populations. Microbiology. 2013; 82:1-10.

6. Kuyukina MS, Ivshina IB. Application of Rhodococcus in bioremediation of contaminated environments. In: Alvarez HM, editor. Biology of Rhodococcus. Microbiology monographs. Volume 16. Springer-Verlag Berlin Heidelberg. 2010; p. 231-262

7. Gurtler V, Seviour RJ. Systematics of members of the genus Rhodococcus (Zopf 1891) Emend Goodfellow, et al. 1998. In: Alvarez HM, editor. Biology of Rhodococcus. Microbiology monographs. Volume 16. Springer-Verlag Berlin Heidelberg. 2010; p. 1-28.

8. Krivoruchko A, Kuyukina M, Ivshina I. Advanced Rhodococcus biocatalysts for environmental biotechnologies. Catalysts. 2019; 9:236.

9. Chen BS, Otten LG, Resch V, Muyzer G, Hanefeld U. Draft genome sequence of Rhodococcus rhodochrous strain ATCC 17895. Stand Genom Sci. 2013; 9(1):175-84.

10. Ansari F, Grigoriev P, Libor S, Tothill IE, Ramsden JJ. DBT degradation enhancement by decorating Rhodococcus erythropolis IGST8 with magnetic $\mathrm{Fe}_{3} \mathrm{O}_{4}$ nanoparticles. Biotechnol Bioeng. 2009; 102(5):1505-1512.

11. Bardania H, Raheb J, Mohammad-Beigi H, Rasekh B, Arpanaei A. Desulfurization activity and reusability of magnetite nanoparticle-coated Rhodococcus erythropolis FMF and $R$. erythropolis IGTS8 bacterial cells. Biotechnol Appl Biochem. 2013; 60(3):323-329.

12. Hou J, Liu F, Wu N, Ju J, Yu B. Efficient biodegradation of chlorophenols in aqueous phase by magnetically immobilized aniline-degrading Rhodococcus rhodochrous strain. J Nanobiotechnology. 2016; 14:5.

13. Ranmadugala D, Ebrahiminezhad A, Manley-Harris M, Ghasemi Y, Berenjian A. Magnetic immobilization of bacteria using iron oxide nanoparticles. Biotechnol Lett. 2018; 40:237248 .

14. Wannoussa W, Masy T, Lambert SD, Heinrichs B, Tasseroul L, Al-Ahmad A, et al. Effect of iron nanoparticles synthesized by a sol-gel process on Rhodococcus erythropolis T902.1 for biphenyl degradation. J Water Resource Prot. 2015; 7:264-277.

15. Auffan M, Achouak W, Rose J, Chanerac C, Waite DT, Masion A, et al. Relation between the redox state of ironbased nanoparticles and their cytotoxicity towards Escherichia coli. Environ Sci Technol. 2008; 42(17):6730-6735.

16. Auffan M, Rose J, Wiesner M, Bottero J. Chemical stability of metallic nanoparticles: a parameter controlling their potential cellular toxicity in vitro. Environ Pollut. 2009; 157(4):1127-1133.

17. Ackermann MA. A functional perspective on phenotypic heterogeneity in microorganisms. Nature Reviews. Microbiology. 2015; 13:497508.

18. González-Cabaleiro R, Mitchell AM, Smith W, Wipat A, Ofițeru ID. Heterogeneity in pure microbial systems: experimental measurements and modeling. Front Microbiol. 2017; 8:1813.

19. Kolomytseva MP, Solyanikova IP, Golovlev EL, Golovleva LA. Heterogeneity of Rhodococcus opacus $1 \mathrm{CP}$ as a response to stress induced by chlorophenols. Appl Biochem Microbiol. 2005; 41(5):474-479. 
20. Solyanikova IP, Suzina NE, Emelyanova EV, Polivtseva VN, Pshenichnikova AB, Lobanok AG, et. Morphological, physiological, and biochemical characteristics of a benzoate-degrading strain Rhodococcus opacus 1CP under stress conditions. Microbiology. 2017; 86(2):202-212.

21. Cincilei A, Tolocichina S, Rastimesina I, Delort A-M, Besse-Hoggan P, Sancelme M. Removal of aqueous benzothiazoles using immobilized bacteria. Proceedings of 34th AMOP Technical Seminar on Environmental Contamination and Response. 2011; 74-82.

22. Gutul T, Rastimesina I, Postolachi O, Nicorici A, Dvornikov D, Petrenco P. Synthesis and biological application of magnetite nanoparticles. Mold J Phys Sci. 2015; 14(3-4):177-188.

23. Yamada T, Takahama Y, Yamada Y. Biodegradation of 2,4-tribromophenol by Ochrobactrum sp. strain TB01. Biosci Biotechnol Biochem. 2008; 72(50):1264-1271.

24. Egorov NS. [Practical Work on Microbiology]. Textbook, Moscow: Publishing house of Moscow. University press. 1995. 307 p. Russian.

25. Calabrese F, Voloshynovska I, Musat F, Thullner M, Schlömann M, Richnow HH. Quantitation and comparison of phenotypic heterogeneity among single cells of monoclonal microbial populations. Front Microbiol. 2019; 10:2814.

26. Grote J, Krysciak D, Streit WR. Phenotypic heterogeneity, a phenomenon that may explain why quorum sensing does not always result in truly homogenous cell behavior. Appl Environ Microbiol. 2015; 81(16):5280-5289.

27. Konovalova EI, Solyanikova IP, Golovleva LA. Degradation of 4-chlorophenol by the strain Rhodococcus opacus 6a. Microbiology. 2009; 78(6):805-807.

28. Stancu MM. Response of Rhodococcus erythropolis strain $\mathrm{IBB}_{\mathrm{Po1}}$ to toxic organic solvents. Braz J Microbiol. 2015; 46(4):1009-1018.

29. Josan V, Rastimesina I, Postolachi O. Influence of support material on heterogeneity of Rhodococcus rhodochrous. Microorganisms: ecology, physiology, biotechnology problems: Materials of all-Russian conference with international participation. Moscow: MAKS Press, 2019. p. 143.

30. Iwabuchi N, Sunairi M, Anzai H, Nakajima M, Harayama SH. Relationships between colony morphotypes and oil tolerance in Rhodococcus rhodochrous. Appl Environ Microbiol. 2000; 66(11):5073-5077.

Received 20.11.2020 